\author{
М.Ю. Сорока ${ }^{1}$, Н.А. Сало ${ }^{1}$ О.Г. Матющенко ${ }^{2}$ \\ ${ }^{1}$ Льотна академія Національного авіаційного університету, Кропивницький \\ ${ }^{2}$ Харківський наџіональний університет Повітряних Сил ім. І. Кожедуба, Харків
}

\title{
ІНТЕЛЕКТУАЛЬНА НАВЧАЛЬНА СИСТЕМА ПІДГОТОВКИ ДИСПЕТЧЕРІВ УПРАВЛІННЯ ПОВІТРЯНИМ РУХОМ
}

В статті розглянуті основні методи організації інтелектуального навчального середовища підготовки диспетчерів управління повітряним рухом. Обгрунтована необхідність створення інтелектуальної навчальної системи в адаптивних тренажерах диспетчерів управління повітряним рухом. Інтелектуальні навчальні системи повинні базуватись на основі синтезу імітаційно-моделюючих комплексів у вигляді розподілених систем обробки даних для імітації поведінки середовища навчання. В роботі сформовані вимоги, щз висуваються до побудови мультиагентного середовища інтелектуальної навчальної системи підготовки диспетчерів управління повітряним рухом. 3 метою забезпечення моделювання інтелектуального поводження об'єктів, щу входять у віртуальне середовище навчання, запропоновано створення інтелектуальних об'єктів, як елементів мультиагентної системи з використанням методів планування дій. Запропоновано підхід удосконалення та розширення функціональних можливостей системи підготовки диспетчерів управління повітряним рухом. Запропонована архітектура інтелектуального агента навчальної системи підготовки диспетчерів управління повітряним рухом створена на базі елементів InterRRa архітектури, що забезпечує взаємодію агента з зовнішнім середовищем та іншими агентами через модель фізичного представлення об'єкта. Наведена математична модель інтелектуального агента в якій враховано можливість здійснення впливу на зовнішнє середовище. Розроблена модель мультиагентного середовища інтелектуальної навчальної системи яка забезпечує ідентифікаџію ситуаџї в підсистемі підготовки і прийняття рішень, щзо виконує передачу управління на відповідний рівень ієрархї̈ системи поводження інтелектуального агента. Особливістю розробленої структури мультиагентного середовища інтелектуальної навчальної системи є використання моделі поведінки інтелектуальних агентів, щзо забезпечують змінну поведінку $i$ можливість рішення задач підготовки і прийняття рішень своїх подальших дій за допомогою різних моделей поведінки.

Ключові слова: управління повітряним рухом, інтелектуальна система, розподілена система, мультиагентна система, штучний інтелект, модель навчання.

\section{Вступ}

Постановка проблеми. Сучасні системи управління повітряним рухом, що реалізовані з використанням інформаційних технологій, викликали значну увагу до інтелектуальних засобів підготовки відповідних фахівців. На сьогоднішній день отримали розвиток навчальні системи, що грунтуються на моделях та методах штучного інтелекту.

Ряд закордонних та вітчизняних науковців вважають [1-4], що на даний час формується та активно розвивається напрямок наукових досліджень в галузі штучного інтелекту у навчальному процесі. Даний напрямок включає методологію психологічних, дидактичних, педагогічних, психологічних, технічних, ергономічних досліджень щодо моделювання поведінки, мотивації людини в процесі засвоєння знань, яке базується на інженерії знань. Підвищення ефективності навчання, інтенсифікація навчального процесу для диспетчерів управління пові- тряним рухом (УПР) та перехід на нові технології неможливий без створення інтелектуальних навчальних систем.

Такі системи повинні базуватись на основі синтезу імітаційно-моделюючих комплексів у складі адаптивних тренажерів реалізованих, як правило, у виді розподілених систем обробки даних, що призначені для імітації поведінки середовища навчання.

Аналіз останніх досліджень і публікацій. Існує велика кількість публікацій як вітчизняних, так і закордонних фахівців, присвячених побудові адаптивних тренажерних систем, які можна умовно поділити на чотири групи: теоретичні роботи в галузі штучного інтелекту та побудови мультиагентних систем [5-7], загальнотеоретичні відносно побудови адаптивних інтелектуальних навчальних систем (в тому числі із застосуванням мультиагентних підходів) [8-11], роботи щодо побудови адаптивних тренажерів авіаційних фахівців (зокрема диспетчерів УПР) [12-14], роботи, присвячені педагогічним та 
дидактичним проблемам автоматизованого навчання [15--18].

Слід зауважити, що на думку даних авторів застосування інтелектуальної навчальної системи в адаптивних тренажерах диспетчерів УПР дозволить суттєво зменшити терміни підготовки диспетчерів управління повітряним рухом та заощадити на фінансових витратах, уникаючи негативного впливу на якість їх підготовки та безпеку польотів.

Формулювання мети статті. Метою статті $\epsilon$ розробка моделі мультиагентного середовища інтелектуальної навчальної системи для підготовки диспетчерів управління повітряним рухом.

\section{Виклад основного матеріалу}

Результати аналізу основних методів організації середовища інтелектуального навчального середовища (IНC) підготовки диспетчерів УПР дозволяють зробити висновки про те, що застосовані підходи не повною мірою забезпечують виконання вимог, що висуваються при розробці сучасних навчальних систем. Варіантом рішення є створення середовища IHC на базі мультиагентних технологій, що $\epsilon$ синтезом технологій штучного інтелекту (Ш) та розподілені системи (РС).

Недоліками існуючого методичного апарата реалізації обчислювально-моделюючих комплексів (OMK) IHC $є$ :

- відсутність єдиних рішень по забезпеченню розподіленого моделювання ситуацій реального часу для диспетчерів УПР;

- складність реалізації інтелектуального поводження об'єктів у IHC;

- труднощі забезпечення єдиного інформаційного простору для розподілених IHC, що вимагають спільної роботи при віддаленні один від одного;

- проблема оперативної адаптації ОМК ІНС для забезпечення імітації об'єктів нових типів з можливостями та характеристиками, що відрізняються від типових.

3 іншого боку, усунення наведених недоліків можливо за рахунок використання засобів і методів, що розробляються в межах теорії мультиагентних систем (МАС).

Одним 3 найважливіших напрямків розвитку сучасних ІНС підготовки диспетчерів УПР є створення середовища, що здатне функціонувати в єдиному інформаційному просторі, виступаючи при цьому активним акцептором і донором даних. 3 іншого боку, значне місце серед проведених досліджень в області мультиагентних систем займають роботи, спрямовані на розробку засобів комунікації агентів. Основною задачею таких досліджень $є$ створення стандартів і уніфікованих підходів, що дозволяють вивести мультиагентні системи на новий якісний рівень свого розвитку.

Завдання підвищення ефективності IHC підготовки диспетчерів УПР за рахунок створення інтелектуального середовища на базі модифікованих методів планування поводження інтелектуальних агентів можна представити в такий спосіб:

$$
\tilde{Z}=F^{*}\left(M^{*}, P^{*}, C^{*}\right) \rightarrow o p t,
$$

де $\tilde{Z}=\left\{z_{1}, z_{2}, \ldots, z_{n}\right\}$ - показники ефективності використання ІНС підготовки диспетчерів УПР в системі підготовки, що відповідають кінцевій меті функціонування системи $Z^{*}$.

$$
M^{*}=\left\{m_{1}, m_{2}, \ldots, m_{k}\right\} \text { - методи планування по- }
$$
ведінки інтелектуальних агентів в IHC ( $k$ - кількість таких методів);

$$
P^{*}=\left\{\left\{p_{11}, p_{12}, \ldots, p_{1 m_{1}}\right\},\left\{p_{21}, p_{22}, \ldots, p_{2 m_{2}}\right\}, \ldots,\right.
$$

$\left.\left\{p_{k 1}, p_{k 2}, \ldots, p_{k m_{k}}\right\}\right\}$ - можливі параметри елементів конфігурації IHC, $m_{i}$ - кількість параметрів $i$-го методу планування поведінки, $i=\{1,2, \ldots, k\}$;

$C^{*} \geq C_{D} ; C_{D}$ - задана продуктивність IHC підготовки диспетчерів УПР;

$$
C=\left\{c_{1}, c_{2}, \ldots, c_{j}\right\} \text { - показники продуктивності }
$$

ІНС в системі підготовці диспетчерів УПР.

3 формули (1) можна зробити висновок, що підвищення ефективності IНС підготовки диспетчерів УПР загалом можливо за рахунок удосконалення методів планування поведінки інтелектуальних агентів та розширення їх функціональних можливостей.

В результаті аналізу побудови МАС, а також вимог до ІНС з підготовки диспетчерів УПР сформовано перелік вимог до інтелектуальних агентів відповідно до пропонованого підходу по створенню мультиагентного середовища IHC підготовки диспетчерів УПР (рис. 1) обчислювально-моделюючого комплексу.

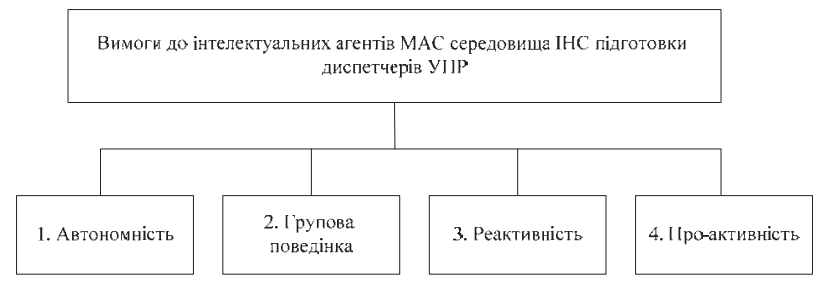

Рис. 1. Вимоги до інтелектуальних агентів

Під інтелектуальним агентом (середовищем) ІНС підготовки диспетчерів УПР розуміють програмну сутність, яка виконує функції цілеспрямованої зміни поведінки об'єкта в середовищі моделю- 
вання. Дана сутність здатна інтерпретувати та виконувати команди і має властивості автономності, колективної поведінки, реактивності, знання, визначення мети, а також здатна адаптуватися до параметрів середовища.

Серед основних систем, які заклали найбільш важливі напрямки розвитку методів планування в теорії розкладів, необхідно виділити наступні (рис. 2).

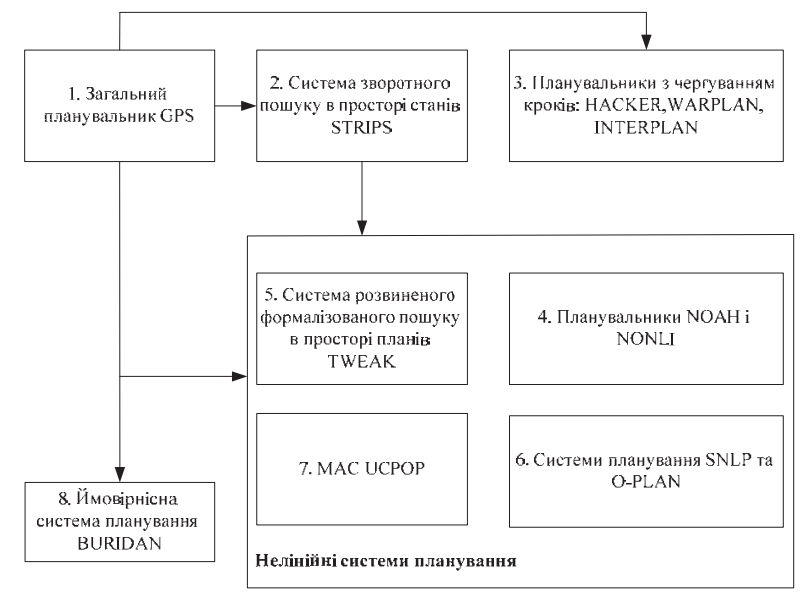

Рис. 2. Взаємозв'язок систем планування поведінки агентів в інтелектуальній навчальній системі

Аналіз існуючих методів планування дозволяє класифікувати використовувані підходи по способу взаємодії із середовищем: автономне планування та інтерактивне планування. Також розрізняють: відкрите та закрите планування. По відношенню до підцілей розрізняють лінійне та нелінійне планування.

Існування залежностей у нелінійному плануванні приводить до необхідності організації чергування дій, спрямованих на досягнення різних підцілей. Існують наступні способи рішення даної задачі: відкладене підтвердження, лінеаризація, розподіленість.

Крім того, використовується поділ на неієрархічне та ієрархічне планування.

Найбільш розповсюджена модель планування полягає в ієрархічній декомпозиції вихідної задачі на підзадачі до максимально досяжного рівня, після чого будуються прості плани досягнення підцілей. Потім 3 цих часткових планів будується повний план досягнення цілі функціонування системи $Z^{*}$.

Альтернативним підходом $\epsilon$ опортуністичне планування, ідея якого базується на спостереженнях за процесом планування людського індивідуума. Фундаментальний аспект складається в спробі розглянути вихідну задачу з різних точок зору, на практиці це реалізується в створенні “віртуальних спеціалістів” - інтелектуальних агентів, що починають діяти при виконанні деяких умов i, у свою чергу, можуть провокувати дії інших агентів.
Основна ідея адаптивного планування полягає в побудові плану за допомогою модифікації деякого вихідного плану, що звичайно береться з бібліотеки рішень за принципом максимальної близькості до даної ситуації в деякому змісті. Основними завданнями при використанні адаптивного планування $є$ : створення бібліотеки планів та отримання критеріїв вибору та створення процедури адаптації, що полягає у зміні порядку кроків алгоритмів, додавання або виключення окремих дій.

При реактивному плануванні інтелектуальний агент не генерує весь план заздалегідь, як у випадку класичного планування.

Після виконання одного або декількох дій агент запускає процедуру повторної генерації плану відносно свого поточного стану.

Модель сприйняття та представлення знань про зовнішне середовище агентом середовища інтелектуальної навчальної системи можна представити у вигляді математичної моделі агента із можливими станами. Агент може бути заданий шістьма параметрами:

$$
A G=(S, A, e n v, I, \text { refine }, \text { action }),
$$

де $S$ - не порожня множина станів зовнішнього середовища;

$A$ - не порожня кінцева множина дій агентів;

env $: S \times A \rightarrow 2^{S}$ - функція поведінки зовнішнього середовища, яка співставляється 3 поточним станом зовнішнього середовища та обраною агентом дією, не порожня множина можливих станів зовнішнього середовища. Таким чином, дії інтелектуального агента навчальної системи можуть впливати на зовнішне середовище, але не контролюють його повністю;

I - не порожня кінцева множина внутрішніх станів інтелектуального агента;

refine $: I(j-1) \times S(j) \rightarrow I(j) \in$ функцією відновлення станів, що співставляє попередньому внутрішньому стану агента $I(j-1)$ та новому стану зовнішнього середовища $S(j)$ новий внутрішній стан агента $I(j)$, де $j$ - стан.

action: $I \rightarrow$ A $€$ функція прийняття рішення, що співставляє поточному внутрішньому стану агента деяку дію.

Дана математична модель інтелектуального агента не породжує інформацію про його внутрішню структуру і зводить опис агента практично до моделі кінцевого автомата 3 вхідним алфавітом $S$, множиною станів $I$ і вихідним алфавітом $A$.

Для моделювання представлення знань інтелектуального агента про поведінку зовнішнього середовища введемо відношення $b e l \subseteq S \times A \times S$. Якщо деяка трійка $\left(s, a, s^{\prime}\right)$ входить до відношення 
$\operatorname{bel}\left(\left(s, a, s^{\prime}\right) \in b e l\right)$, то за представленням агента, при виконанні дій а в стані зовнішнього середовища $s$, зовнішнє середовище може перейти до стану $s^{\prime}$.

Таким чином, знання агента про зовнішне середовище по своїй структурі аналогічні опису поведінки зовнішнього середовища env, та за своїм змістом є моделлю зовнішнього середовища з боку агента. Якщо для будь-яких $\left(s, s^{\prime}\right) \in S$ та $a \in A$ виконується тотожність $s^{\prime} \in e n v(s, a)$ тоді і тільки тоді, коли $\left(s, a, s^{\prime}\right) \in b e l$. Таким чином представлення агента повністю відповідає реальності (в цьому випадку представлення можна вважати знаннями). Множина всіх можливих представлень має вигляд: $\operatorname{Bel}(S, A) \equiv 2^{S \times A \times S}$.

Представлення агента можуть обновлюватися на кожному кроці взаємодії з зовнішнім середовищем шляхом введення функції оновлення представлень:

$$
\text { brf : } I_{b e l} \times \operatorname{Bel}(S, A) \times A \times P \rightarrow I_{b e l} \times \operatorname{Bel}(S, A),(3)
$$

яка співставляє елементи поточного внутрішнього стану агента $i_{b e l} \in I_{b e l}$ поточним представленням bel $\in \operatorname{Bel}(S, A)$ відтворений агентом дії $a \in A$ та сприйняття нового стану зовнішнього середовища $p \in P \quad$ нового елементу внутрішнього стану $i_{b e l}^{\prime} \in I_{b e l} \quad$ та нове відношення представлень bel' $^{\prime} \in \operatorname{Bel}(S, A)$.

В результаті процес оновлення представлення агента моделюється детермінованим кінцевим автоматом 3 вхідним алфавітом $A \times P$ та множиною внутрішніх станів $I_{b e l} \in \operatorname{Bel}(S, A)$. Множина $I_{B}=I_{b e l} \times \operatorname{Bel}(S, A) \quad \epsilon$ частиною множини внутрішніх станів агента $I$ в тому змісті, що $I=I_{B} \times I^{\prime}$ (де $I^{\prime}$ - деяка додаткова частина стану невизначеної структури). Для ілюстрації процесу оновлення знань агента про зовнішнє середовище розглянемо приклад агента 3 абсолютною пам'яттю. В даному випадку $I_{b e l}$ може співпадати з множиною можливих сприйнять $P$ та використовуватися для зберігання попереднього стану зовнішнього середовища. В цьому випадку функція $b r f$ може бути обчислена за наступномим алгоритмом:

$$
\operatorname{brf}\left(i_{b e l}, b e l, a, p^{\prime}\right)=\left(i_{b e l}^{\prime}=p^{\prime}, b e l^{\prime}=b e l \cup p \times\{a\} \times p^{\prime}\right) .
$$

Таким чином, після кожної ітерації взаємодії з зовнішнім середовищем в базу знань агентів додається множина фактів виду $\left(s, a, s^{\prime}\right)$, де $s \in p$, $s^{\prime} \in p^{\prime} \quad$ (кожне сприйняття $p$ представляє собою клас еквівалентності на множині $S$ ). Додані в базу знань факти описують результати тільки що пройденої ітерації взаємодії з зовнішнім середовищем.
Оскільки ключовим елементом середовища інтелектуальної навчальної системи підготовки диспетчерів управління повітряним рухом $\epsilon$ інтелектуальний агент, призначений для моделювання поведінки об'єктів реального світу в навчальній системі, для реалізації даного агента розроблено розширену модель від моделі (2), що можна представити у вигляді кортежу виду:

$$
I A G=\left(R_{A}, P_{A}, C_{A}, S, A, P, R, R I\right),
$$

де $R_{A}$ - модель реактивної поведінки;

$P_{A}$ - модель планування поведінки;

$C_{A}$ - модель колективної поведінки;

$S$ - множина станів моделей;

A - множина дій;

$R \mathrm{R}$ - множина знань агентів;

$R_{I}$ - множина відношень між елементами моделі.

Для реалізації даної моделі в роботі розроблена структура інтелектуального агенту на базі елементів InterRRa apхітектури [5]. Створена архітектура приведена на рис. 3 .

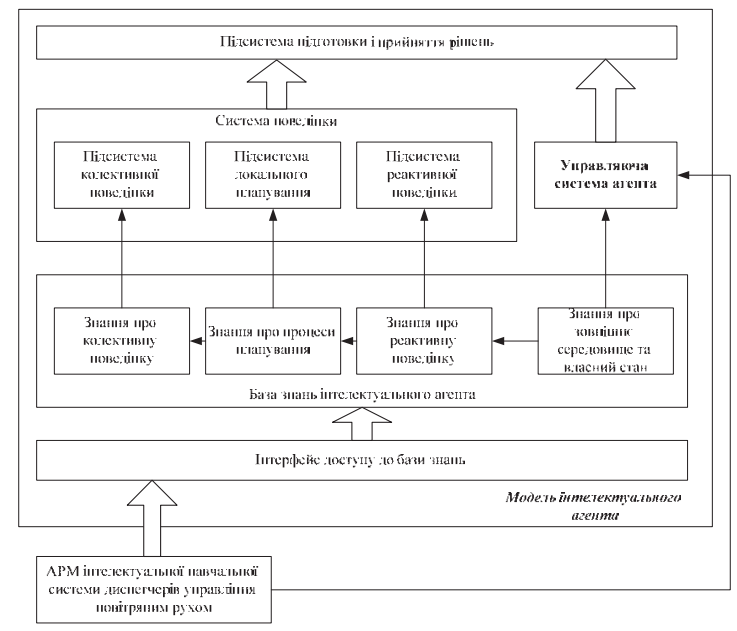

Рис. 3. Архітектура інтелектуального агенту навчальної системи підготовки диспетчерів управління повітряним рухом

Особливістю розробленої структури є те, що взаємодія агента 3 зовнішнім середовищем, у тому числі з іншими агентами, здійснюється через модель фізичного представлення об'єкта. Таким чином, досягається поділ моделювання інтелектуального поводження об'єктів у середовищі навчальної системи від їх фізичного представлення, у яке в тому числі можуть входити засоби комунікації. У той же час запропонована на рис. 3 структура допускає прямі керуючі впливи на поведінку агентів 3 автоматизованих робочих місць начальної системи диспетчерів управління повітряним рухом 3 метою забезпечення можливості внесення корегувань у розвиток навча- 
льної обстановки (середовища), а також доступ до бази знань агента за допомогою спеціального інтерфейсу.

Основною відмінністю даного підходу від закладених в InteRRa архітектуру принципів є те, що загальне керування поведінкою здійснюється не шляхом комунікації між рівнями поведінки, яка здійснюється за рахунок передачі керування знизу нагору доти, поки не буде досягнутий рівень, здатний справитися з ситуацією, що склалася.

Розроблена структура забезпечує ідентифікацію ситуації в підсистемі підготовки і прийняття рішень, що виконує передачу управління на відповідний рівень ієрархії системи поводження інтелектуального агента. Крім того, підсистема підготовки і прийняття рішень відслідковує інформацію, що надходить 3 рівнів поводження агентів, та у випадку виникнення суперечливих ситуацій забезпечує їх розв'язання. Таким чином, запропонований підхід реалізує взаємодію рівнів через посередника як підсистеми підготовки і прийняття рішень. Такий підхід обумовлений великою відповідністю функціональних можливостей компонентів InteRRa apхітектури для реалізації запропонованого підходу, а спосіб організації управління більш близький до підходів сучасних інтелектуальних навчальних систем.

Реалізація рівнів реактивної $\left(R_{A}\right)$ та колективної поведінки $R_{A}$ може бути здійснений на основі існуючого методичного апарату, що використовується для створення сучасних інтелектуальних навчальних систем.

В рамках агенто-орієнтованого підходу розроблена наступна модель мультиагентного середовища інтелектуальної навчальної системи підготовки диспетчерів повітряного руху:

$$
V_{S}=(W, E, O, R, C, S t)
$$

де $W=\left\{w_{1}, w_{2}, \ldots, w_{s}\right\}$ - множина моделей об'єктів реального світу в середовищі інтелектуальної навчальної системи;

$$
E=\left\{e_{1}, e_{2}, \ldots, e_{t}\right\}-\text { множина моделей середо- }
$$
вищ;

$$
O=\left\{\left\{o_{1}^{U}, o_{2}^{U}, \ldots, o_{n}^{U}\right\},\left\{o_{1}^{I}, o_{2}^{I}, \ldots, o_{k}^{I}\right\}\right\}-\text { множина }
$$

неоднорідних об'єктів (агентів) середовища навчальної інтелектуальної системи, де:

$o_{i}^{U}$ - модель об'єкта $i=\{1,2, \ldots n\}$, керування якою здійснює диспетчер управління повітряним рухом, де $n$ - кількість моделей, які управляються оператором;

$$
o_{j}^{I} \quad \text { - інтелектуальна модель об’єкту }
$$

$j=\{1,2, \ldots k\}$, де $k$ - кількість інтелектуальних моделей управління;
$R$ - множина відношень між елементами системи;

C - множина зовнішніх дій (дії диспетчера управління повітряним рухом);

St - множина станів системи.

В свою чергу керування диспетчером управління повітряним рухом моделі об'єкта системи можна представити як: $o_{i}^{U}=\left\{P h_{i}, A c_{i}\right\}$, де $P h_{i}-$ модель фізичного представлення об'єкту; $A c_{i}$ - модель поведінки, яка піддається керуючому впливу. Інтелектуальну модель об'єкта пропонується представити наступним чином: $o_{j}^{i}=\left\{P h_{j}, I A G_{i}\right\}$, де $I A G_{i}$ - відповідає моделі (5).

Для наведеної моделі мультиагентного середовища інтелектуальної навчальної системи підготовки диспетчерів управління повітряним рухом розроблена структура, що представлена на рис. 4 .

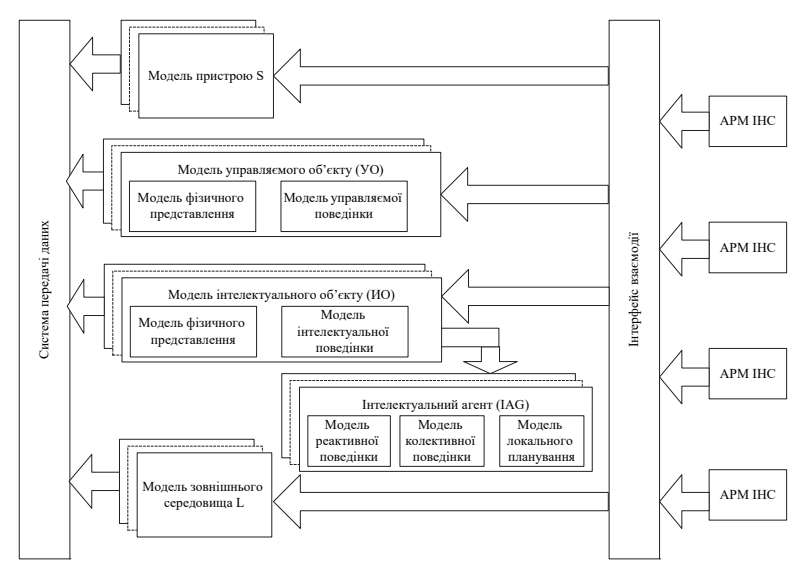

Рис. 4. Модель мультиагентного середовища інтелектуальної навчальної системи

В наведеній на рис. 4 структурі використані наступні позначення:

- модель УО - управляємий об'єкт, де $i=\{1,2, \ldots n\}-$ кількість об'єктів;

- модель IО - інтелектуальний об'єкт, де $j=\{1,2, \ldots k\}$ - кількість інтелектуальних об'єктів;

- АРМ - автоматизоване робоче місце інтелектуальної системи підготовки диспетчера управління повітряним рухом;

$S$ - кількість моделей пристроїв;

$L$ - кількість моделей середовища.

Основною особливістю розробленої структури мультиагентного середовища інтелектуальної навчальної системи є використання моделі поведінки інтелектуальних агентів, що забезпечують змінну поведінку і можливість рішення задач підготовки і прийняття рішень своїх подальших дій за допомогою різних моделей поведінки. 


\section{Висновки}

Обчислювально-моделюючі комплекси як технології реалізації моделі середовища сучасних IHC у більшості випадків реалізовані у вигляді складних розподілених програм. Одним 3 перспективних підходів до розробки таких систем є використання мультиагентних технологій. У зв'язку з цим у статті запропоновано використовувати агентно-орієнтований підхід до побудови середовища IHC підготовки диспетчерів УПР. В основі реалізації інтелектуальної поведінки об’єктів у рамках даного підходу пропонується використовувати методи планування поведінки інтелектуальних агентів.

Запропоновано підхід удосконалення та розширення функціональних можливостей системи підготовки диспетчерів УПР за рахунок використання теорії мультиагентних систем 3 метою створення IHC, що забезпечує правдоподібність та нелінійності поводження об'єктів, що імітуються в IHC.

Сформовані вимоги до побудови мультиагентного середовища інтелектуальної навчальної системи підготовки диспетчерів управління повітряним рухом, розроблені моделі такої системи.

\section{Список літератури}

1. Федорук П.І. Адаптивна система дистанційного навчання та контролю знань на базі інтелектуальних інформаційних технологій [Текст]: автореферат дис ... докт. техн. наук: 05.13.06 / Федорук Павло Іванович. - К.: НАН України, Інститут проблем математичних машин і систем, 2009. - 42 с.

2. Kaczor K. Overview of Expert System Shells / K. Kaczor, B. Szymon, J. Grzegorz. - Krakow, Poland: Institute of Automatics: AGH University of Science and Technology, Poland, 5 December 2010. - 334 p.

3. Dignum V. Modelling agent societies: co-ordination frameworks and institutions / V. Dignum, F. Dignum // Progress in Artificial Intelligence: Knowledge Extraction, Multi-agent Systems, Logic Programming, and Constraint Solving, LNAI 2258. Springer, 2001. - P. 191-204.

4. Railsback S. Agent-based and Individual-based Modeling: A Practical Introduction / S. Railsback, V. Grimm // Princeton University Press, 2011. - 329 c.

5. Багрецов С.А. Методические рекомендации по оценке дидактической эффективности обучающих систем/ С.А. Багрецов, Г.М. Попов. - Л.: МО СССР, 1988. - 132 с.

6. Фин В.К. Об интеллектуальном анализе данных / В.К. Фин // Новости Искусственного интеллекта. - 2004. № 3. - С. 98-103.

7. Магид С.И. Использование современных информационных технологий при разработке тренажеров для тепловых электрических станций / С.И. Магид, М.И. Кузнецов, Е.И. Архинова // Энергосбережение и водоподготовка. - 2004. - №2. - C. 26-30.

8. Decision table for adaptive e-learning systems / P. Ardimento, N. Boffoli, V.N. Convertini, G. Visaggio // Education in a Technological World: Communicating Current and Emerging Research and Technological Efforts. - Publisher: Formatex Research Center, December 2011. - P. 127-134.

9. AutoTutor: A tutor with dialogue in natural language [Electronic resource] / A.C. Graesser, S. Lu, G.T. Jackson, H.H. Mitchell, M. Ventura, A. Olney, M.M. Louwerse // Behavior Research Methods, Instruments \& Computers. - 2004. No. 36(2). - $\quad$ Available at: https://www.researchgate.net/profile/Max_Louwerse/publication/ 215835920_AutoTutor_a_Tutor_with_Dialogue_in_Natural_Language/links/0912f509d1255b8dcc000000/AutoTutor-a-Tutorwith-Dialogue-in-Natural-Language.pdf. - (дата звернення 10.09.2019).

10. Oxman S. White paper: adaptive learning systems / S. Oxman, W. Wong. - DV X InnovationsDeVry Education Group. - February 2014. -30 p.

11.Титенко С.В. Дослідження і аналіз методів та моделей інтелектуальних систем безперервного навчання / С.В. Титенко // Наукові вісті НТУУ “КПІ”. - 2007. - № 6(56). - С. 37-48.

12.Горенков А.Н. Современные тренажёрные и моделирующие комплексы в системе профессиональной подготовки управления воздушным движением / А.Н. Горенков // Транспортное дело. - 2016. - № 4. - С. 70-73.

13. Неділько В.М. Проблеми побудови системи адаптивної тренажерної підготовки диспетчерів управління повітряним рухом / В.М. Неділько, А.С. Пальоний, К.Ю. Сурков // Радіоелектронні і комп’ютерні системи. - 2017. - № 4. C. 64-72.

14. Литвин В.В. Мультиагентні системи підтримки прийняття рішень, що базуються на прецедентах та використовують адаптивні онтології / В.В. Литвин // Штучний інтелект. - 2009. - № 2. - С. 24-33.

15. Сергеев С.Ф. Введение в инженерную психологию и эргономику иммерсивных сред / С.Ф. Сергеев. - СПб: Издво СПбГУ ИТМО, 2011. - 258 с.

16. Талызина Н.Ф. Управление процессом усвоения знаний / Н.Ф. Талызина. - М.: МГУ, 1975. - 343 с.

17. Юрков Н.К. Машинный интеллект и обучение человека: монография / Н.К. Юрков. - Пенза: ИИЦ ПензГУ, 2008. $-226 \mathrm{c}$.

18. Effectiveness of Part-Task Training and Increasing-Difficulty Training Strategies: A Meta-Analysis Approach / C.D. Wickens, S. Hutchins, T. Carolan, J. Cumming // Human Factors: The Journal of the Human Factors and Ergonomics Society. - 2012. - Vol. 55, No. 2. - P. 461-470. https://doi.org/10.1177/0018720812451994. 


\section{References}

1. Fedoruk, P.I. (2009), “Adaptyvna systema dystantsiynoho navchannya ta kontrolyu znan' na bazi intelektual'nykh informatsiynykh tekhnolohiy: avtoreferat dysertatsiyi" [Adaptive System of Distance Learning and Knowledge Control on the Basis of Intellectual Information Technologies: dissertation abstract], Institute of Problems of Mathematical Machines and Systems, Kyiv, $42 \mathrm{p}$.

2. Kaczor, K., Szymon, B. and Grzegorz, J. (2010), Overview of Expert System Shells, Institute of Automatics: AGH University of Science and Technology, Krakow, Poland, $334 \mathrm{p}$.

3. Dignum, V. and Dignum, F. (2001), Modelling agent societies: co-ordination frameworks and institutions, Progress in Artificial Intelligence: Knowledge Extraction, Multi-agent Systems, Logic Programming, and Constraint Solving, LNAI 2258, Springer, pp. 191-204.

4. Railsback, S. and Grimm, V. (2011), Agent-based and Individual-based Modeling: A Practical Introduction, Princeton University Press, 329 p.

5. Bagretsov, S.A. and Popov, G.M. (1988), "Metodicheskiye rekomendatsii po otsenke didakticheskoy effektivnosti obuchayushchikh sistem" [Guidelines for assessing the didactic effectiveness of teaching systems], Leningrad, USSR, $132 \mathrm{p}$.

6.Fin, V.K. (2004), "Ob intellektual'nom analize dannykh" [About data mining], Novosti iskusstvennogo intellekta, No. 3 , pp. 98-103.

7.Magid, S.I., Kuznetsov, M.I. and Arkhinova, Ye.I. (2004), "Ispol'zovaniye sovremennykh informatsionnykh tekhnologiy pri razrabotke trenazherov dlya teplovykh elektricheskikh stantsiy" [The use of modern information technology in the development of simulators for thermal power plants], Energy conservation and water treatment, No. 2, pp. 26-30.

8.Ardimento, P. Boffoli, N., Convertini, V.N. and Visaggio, G. (2011), Decision table for adaptive e-learning systems, Education in a Technological World: Communicating Current and Emerging Research and Technological Efforts, Formatex Research Center, pp. 127-134.

9. Graesser, A.C., Lu, S., Jackson, G.T., Mitchell, H.H., Ventura, M., Olney, A. and Louwerse, M.M. (2004), AutoTutor: A tutor with dialogue in natural language, Behavior Research Methods, Instruments \& Computers, No. 36(2), available at: www.researchgate.net/profile/Max_Louwerse/publication/215835920_AutoTutor_a_Tutor_with_Dialogue_in_Natural_Language/ links /0912f509d1255b8dcc000000/AutoTutor-a-Tutor-with-Dialogue-in-Natural-Language.pdf (Date of access: 10.09.2019).

10. Oxman, S. and Wong, W. (2014), White paper: adaptive learning systems, DV X InnovationsDeVry Education Group, $30 \mathrm{p}$.

11. Tytenko, S.V. (2007), "Doslidzhennya i analiz metodiv ta modeley intelektual'nykh system bezperervnoho navchannya" [Research and analysis of methods and models of intellectual systems of lifelong learning], Scientific News of NTUU “KPI”, No. 6(56), pp. 37-48.

12. Gorenkov, A.N. (2016), "Sovremennyye trenazhornyye i modeliruyushchiye kompleksy v sisteme professional'noy podgotovki upravleniya vozdushnym dvizheniyem" [Modern training and modeling systems in the system of professional training of air traffic control], Transport, No. 4, pp. 70-73.

13. Nedil'ko, V.M., Pal'onyy, A.S. and Surkov, K.Yu. (2017), "Problemy pobudovy systemy adaptyvnoyi trenazhernoyi pidhotovky dyspetcheriv upravlinnya povitryanym rukhom" [Problems of constructing a system of adaptive training for controllers of wind control], Radioelectronic and computer systems, No. 4, pp. 64-72.

14. Lytvyn, V.V. (2009), "Mul'tyahentni systemy pidtrymky pryynyattya rishen', shcho bazuyutsya na pretsedentakh ta vykorystovuyut adaptyvni ontolohiyi” [Multiagent Case-Based Decision Support Systems Using Adaptive Ontologies], Artificial Intelligence, No. 2, pp. 24-33.

15. Sergeyev, S.F. (2011), "Vvedeniye v inzhenernuyu psikhologiyu i ergonomiku immersivnykh sred" [Introduction to engineering psychology and ergonomics of immersive environment], St. Petersburg, $258 \mathrm{p}$.

16. Talyzina, N.F. (1975), "Upravleniye protsessom usvoyeniya znaniy" [Management of the process of assimilation of knowledge], Moscow, $343 \mathrm{p}$.

17. Yurkov, N.K. (2008), "Mashinnyy intellekt i obucheniye cheloveka: monografiya" [Machine intelligence and human training: monograph], Penza, 226 p.

18. Wickens, C.D. Hutchins, S., Carolan, T. and Cumming, J. (2012), Effectiveness of Part-Task Training and IncreasingDifficulty Training Strategies: A Meta-Analysis Approach, Human Factors: The Journal of the Human Factors and Ergonomics Society, Vol. 55, No. 2, pp. 461-470. https://doi.org/10.1177/0018720812451994.

Надійшла до редколегії 26.02.2020

Схвалена до друку 14.04.2020

Відомості про авторів:

\section{Сорока Михайло Юрійович}

старший викладач

Льотної академії

національного авіаційного університету,

Кропивницький, Україна

http://orcid.org/0000-0003-1894-4002
Information about the authors:

\author{
Myhaylo Soroka \\ Senior Instructor \\ of National Aviation University \\ "Flight Academy of the National Aviation University", \\ Kropyvnytskyy, Ukraine \\ http://orcid.org/0000-0003-1894-4002
}


Сало Наталія Анатоліївна

старший викладач

Льотної академії

національного авіаційного університету,

Кропивницький, Україна

https:/orcid.org/0000-0003-1422-9853
Natalia Salo

Senior Instructor

of National Aviation University

"Flight Academy of the National Aviation University",

Kropyvnytskyy, Ukraine

https://orcid.org/0000-0003-1422-9853

\section{Olga Matiushchenko}

Doctoral Student

of Ivan Kozhedub Kharkiv National

Air Force University,

Kharkiv, Ukraine

https://orcid.org/0000-0003-4843-8258

\title{
ИНТЕЛЛЕКТУАЛЬНАЯ ОБУЧАЮЩАЯ СИСТЕМА ПОДГОТОВКИ ДИСПЕТЧЕРОВ УПРАВЛЕНИЯ ВОЗДУШНЫМ ДВИЖЕНИЕМ
}

М.Ю. Сорока, Н.А. Сало, О.Г. Матющенко

В статье рассмотрены основные методы организачии интеллектуальной обучающей среды подготовки диспетчеров управления воздушным движением. Обоснована необходимость создания интеллектуальной обучающей системы в адаптивных тренажерах диспетчеров управления воздушным движением. Интеллектуальные обучающие системы должны базироваться на основе синтеза имитационно-моделирующих комплексов в виде распределенных систем обработки данных для имитации поведения среды обучения. В работе сформированы требования, предъявляемые к построению мультиагентной среды интеллектуальной обучающей системы подготовки диспетчеров управления воздушным движением. С иелью обеспечения моделирования интеллектуального поведения объектов, входящих в виртуальную среду обучения предложено создание интеллектуальных объектов, как элементов мультиагентной системы с использованием методов планирования действий. Предложен подход усовершенствования и расширения функииональных возможностей системы подготовки диспетчеров управления воздушным движением. Предложена архитектура интеллектуального агента обучающей системы подготовки диспетчеров управления воздушным двиюением созданая на базе элементов InterRRa архитектуры, которая обеспечивает взаимодействие агента с внешней средой и другими агентами через модель физического представления объекта. Приведена математическая модель интеллектуального агента, в которой учтена возможность оказания влияния на окружающую среду. Разработанная модель мультиагентной среды интеллектуальной обучающей системы, обеспечивающей идентификацию ситуации в подсистеме подготовки и принятия решений, выполняет передачу управления на соответствующий уровень иерархии системы обращения интеллектуального агента. Особенностью разработанной структуры мультиагентной среды интеллектуальной обучающей системы является использование модели поведения интеллектуальных агентов, обеспечивающих перемену поведения своих дальнейших действий и возможность решения задач подготовки и принятия решений с помощью различных моделей поведения.

Ключевые слова: управления воздушным движением, интеллектуальная система, распределенная система, мультиагентная система, искусственный интеллект, модель обучения.

\section{INTELLIGENT TRAINING SYSTEM FOR TRAINING MANAGEMENT CONTROLLERS BY AIR TRAFFIC}

\author{
M. Soroka, N. Salo, O. Matiushchenko
}

The article describes the basic methods of organizing an intelligent learning environment for the training of air traffic controllers. The necessity of creating an intelligent training system in adaptive simulators of air traffic controllers is substantiated. In order to provide modeling of the intellectual behavior of objects included in the virtual learning environment, the creation of intelligent objects as elements of a multi-agent system using action planning methods is proposed. Intelligent learning systems should be based on the synthesis of simulation-modeling systems in the form of distributed data processing systems to simulate the behavior of the learning environment. The work contains the requirements for the construction of a multi-agent environment of an intelligent educational system for training air traffic controllers. An approach is proposed for improving and expanding the functionality of the training system for air traffic controllers. The proposed architecture of the intelligent agent of the training system for the training of air traffic controllers created on the basis of InterRRa architecture elements, which provides the agent's interaction with the environment and other agents through the model of the physical representation of the object. A mathematical model of an intelligent agent is presented in which the possibility of influencing the environment is taken into account. The developed model of the multi-agent environment of an intelligent learning system that provides identification of the situation in the subsystem for preparing and making decisions, transfers control to the appropriate level of the hierarchy of the intelligent agent circulation system. A feature of the developed structure of the multi-agent environment of an intelligent learning system is the use of the behavior model of intelligent agents that provide a change in the behavior of their further actions and the ability to solve training and decision-making problems using various behavior models.

Keywords: air traffic control, intelligent system, distributed system, multi-agent system, artificial intelligence, training model. 